in vivo $34: 2461-2467$ (2020)

doi:10.21873/invivo.12061

\title{
Casticin Inhibits In Vivo Growth of Xenograft Tumors of Human Oral Cancer SCC-4 Cells
}

\author{
HUNG-SHENG SHANG ${ }^{1,2 \#}$, KUO-WEI CHEN ${ }^{3 \#}$, JIANN-SHANG CHOU ${ }^{4}$, SHU-FEN PENG $^{5,6}$, \\ YUNG-LIANG CHEN ${ }^{7}$, PO-YUAN CHEN ${ }^{5}, \mathrm{HSIEH}^{-C H O U} \mathrm{HUANG}^{8,9}$, HSU-FENG LU $^{10,11}$, \\ HSIN-YU CHANG ${ }^{10}$, YUNG-LUEN SHIH ${ }^{12,13,14^{*}}$ and WEN-WEN HUANG ${ }^{5^{*}}$ \\ ${ }^{I}$ Graduate Institute of Clinical of Medicine, College of Medicine, Taipei Medical University, Taipei, Taiwan, R.O.C.; \\ ${ }^{2}$ Division of Clinical Pathology, Department of Pathology, Tri-Service General Hospital, \\ National Defense Medical Center, Taipei, Taiwan, R.O.C.; \\ ${ }^{3}$ Division of Hematology and Oncology, Cheng Hsin General Hospital, Taipei, Taiwan, R.O.C.; \\ ${ }^{4}$ Department of Anatomic Pathology, Cheng Hsin General Hospital, Taipei, Taiwan, R.O.C.; \\ ${ }^{5}$ Department of Biological Science and Technology, China Medical University, Taichung, Taiwan, R.O.C.; \\ ${ }^{6}$ Department of Medical Research, China Medical University Hospital, Taichung, Taiwan, R.O.C.; \\ ${ }^{7}$ Department of Medical Laboratory Science and Biotechnology, Yuanpei University, Hsinchu, Taiwan, R.O.C.; \\ ${ }^{8}$ Anesthesiology and Pain Medicine, Cheng Hsin General Hospital, Taipei, Taiwan, R.O.C.; \\ ${ }^{9}$ Department of Pharmacology, National Defense Medical Center, Taipei, Taiwan, R.O.C.; \\ 10Department of Clinical Pathology, Cheng Hsin General Hospital, Taipei, Taiwan, R.O.C.; \\ ${ }^{11}$ Department of Restaurant, Hotel and Institutional Management, Fu-Jen Catholic University, New Taipei, Taiwan, R.O.C.; \\ ${ }^{12}$ School of Medicine, College of Medicine, Fu-Jen Catholic University, New Taipei, Taiwan, R.O.C.; \\ ${ }^{13}$ Department of Pathology and Laboratory Medicine, Shin Kong Wu Ho-Su Memorial Hospital, Taipei, Taiwan, R.O.C.; \\ ${ }^{14}$ School of Medical Laboratory Science and Biotechnology, Taipei Medical University, Taipei, Taiwan, R.O.C.
}

\begin{abstract}
Background/Aim: Casticin, one of the active components of Vitex rotundifolia L., presents biological and pharmacological activities including inhibition of migration, invasion and induction of apoptosis in numerous human cancer cells in vitro. This study aimed to assess the effects of casticin on tumor growth in a human oral cancer SCC-4 cell xenograft mouse model in vivo. Materials and Methods: Twenty-four nude mice were injected subcutaneously with
\end{abstract}

This article is freely accessible online.

*, \#These Authors contributed equally to this work.

Correspondence to: Yung-Luen Shih, Ph.D., Department of Pathology and Laboratory Medicine, Shin Kong Wu Ho-Su Memorial Hospital, No 95, Wen-Chang Road, Shih-Lin, Taipei city, Taiwan, R.O.C. Tel: +886 228332211 ext. 2128 , Fax: +886 228389360, e-mail: t005524@ms.skh.org.tw; Wen-Wen Huang, Ph.D., Department of Biological Science and Technology, China Medical University, No 91, Hsueh-Shih Road, Taichung, Taiwan, R.O.C. Tel: +886 422053366 ext. 2527, Fax: +886 422053764, e-mail: wwhuang@mail.cmu.edu.tw

Key Words: Casticin, Human oral cancer SCC-4 cells, xenograft mice, in vivo.
SCC-4 cells and when palpable tumors reached a volume of $100-120 \mathrm{~mm}^{3}$ the mice were randomly divided into three groups. The control (0.1\% dimethyl sulfoxide), casticin $(0.2$ $\mathrm{mg} / \mathrm{kg})$, and casticin $(0.4 \mathrm{mg} / \mathrm{kg})$ groups were intraperitoneally injected every two days for 18 days. Tumor volume and body weights were measured every two days. Results: Casticin significantly decreased tumor volume and weight in SCC-4 cell xenograft mice but there was no statistically significant difference between the body weights of control mice and mice treated with $0.2 \mathrm{mg} / \mathrm{kg}$ or $0.4 \mathrm{mg} / \mathrm{kg}$ casticin. Therefore, the growth of SCC-4 cells in athymic nude mice can be inhibited by casticin in vivo. Conclusion: These findings support further investigations in the potential use of casticin as an oral anticancer drug in the future.

Oral cancer has high mortality and morbidity (1) that appears on the lips, cheeks, tongue, gingiva, the floor of the mouth, hard and soft palate, sinuses, and pharynx (2). Oral squamous cell carcinoma (OSCC) is one of the leading cancers worldwide, representing over $90 \%$ of malignant neoplasms of the mouth $(3,4)$. However, OSCC occurs more frequently in individuals with oral bacterial infections such as higher levels of periodontal pathogenic bacteria in OSCC surfaces (5). In the USA, about 11.3 new cases of oral cancer per 100,000 people are diagnosed every year (6). In Canada, 


\section{Injection SCC-4 cells \\ $\left(1 \times 10^{7}\right.$ cells/mouse $)$}

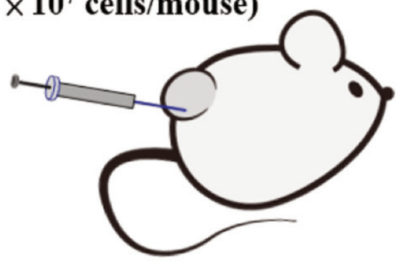

$\longrightarrow$ Tested groups
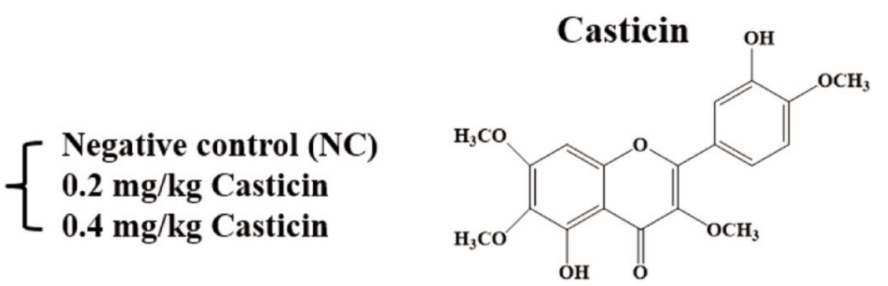

Measurement of tumor size
Day 10

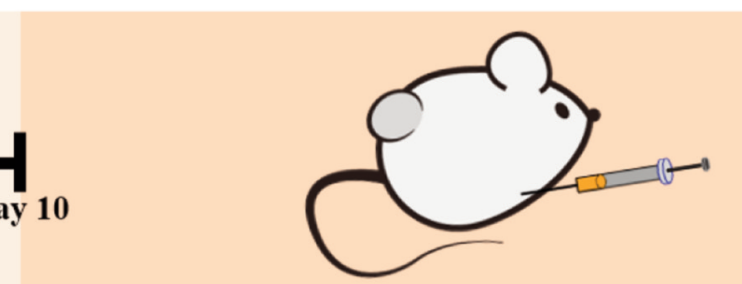

$>$ Casticin was i.p. injected once every two days.

Measurement of body weight and tumor size every two days.

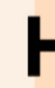

Day

0
Day 18

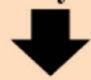

Measurement of body weight and tumor weight

Figure 1. The experimental design for examining the effects of casticin on human oral cancer cell xenograft mice. A total of twenty-four nude mice were individually injected with $1 \times 10^{7} \mathrm{SCC}-4$ cells. All animals were randomized into three different treatment groups (control, $0.2 \mathrm{mg} / \mathrm{kg}$ and 0.4 $\mathrm{mg} / \mathrm{kg}$ ) ( $\mathrm{n}=8$ for each group) when the tumor volume reached $100-120 \mathrm{~mm}^{3}$. Casticin $(0.2$ and $0.4 \mathrm{mg} / \mathrm{kg}$ ) was administered every two days by intraperitoneal injection. All mice were sacrificed 18 days after treatment.

4,600 new cases of oral cancer are diagnosed per year (7). In Taiwan, 12.1 individuals per 100,000 die annually from oral cancer and it is the fifth most common cancer based on the 2018 report from the Ministry of Health and Welfare, Taiwan, ROC (8), but betel chewing has been recognized to be one of the major factors for oral cancer in Taiwan (9). Currently, the treatments of oral cancer include primary surgery, chemotherapy and radiation therapy or the combination of chemo- and radio-therapy but the outcomes are still unsatisfied because of the side effects; thus, numerous studies have focused on finding new compounds from natural products.

Casticin (3', 5-dihydroxy-3, 4', 6, 7-tetramethoxyflavone), vitexicarpin, is a flavonoid $(10,11)$ from the Chinese herb Vitex Fructus (10) and is also present in other fruits, herbs, and spices (12). Casticin has long been used as an anti-inflammatory drug in traditional Chinese medicine $(13,14)$. It has been shown to exert biological and pharmacological effects, especially anti-cancer activities in vitro and in animal models in vivo (15-17). Casticin induced apoptosis in many human cancer cells such as bladder (18), cervical (19) and ovarian cells (20) and
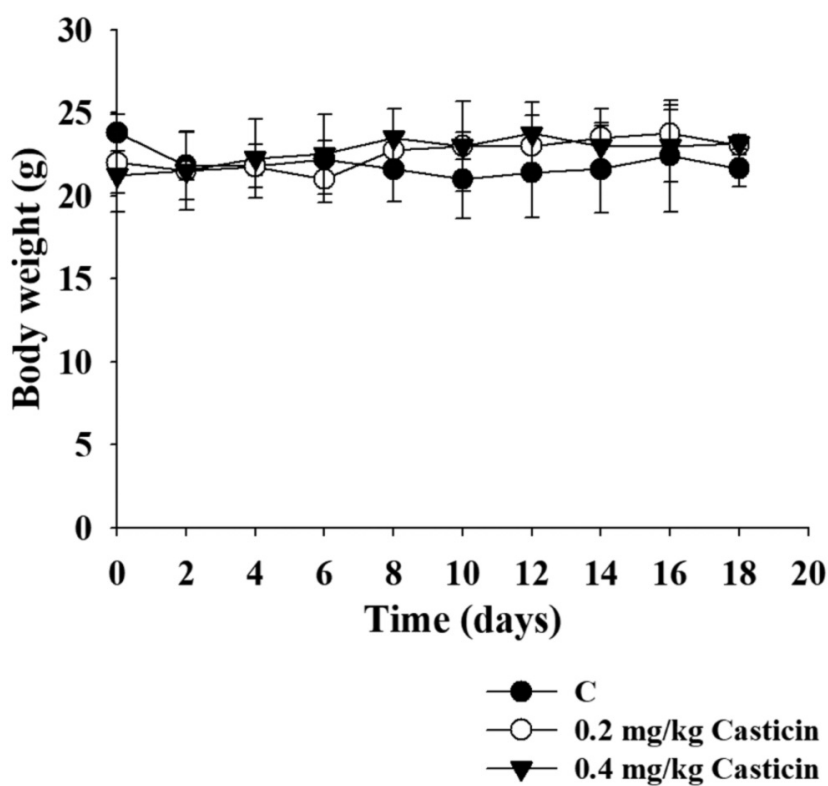

Figure 2. The effect of casticin on the body weight of SCC-4 cell xenograft mice. The body weights were measured and recorded every 2 days for a total of 18 days. 
A

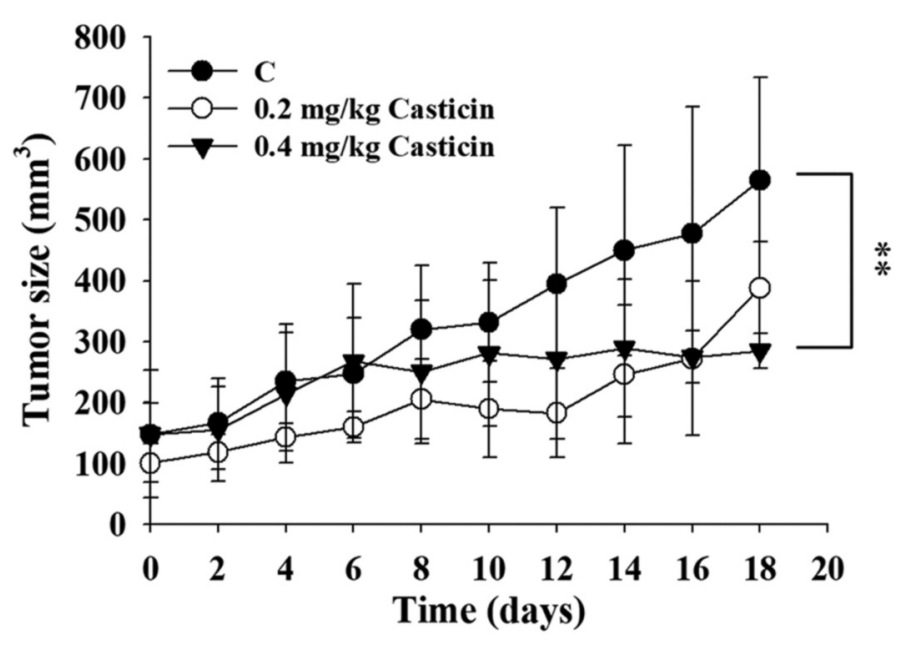

B

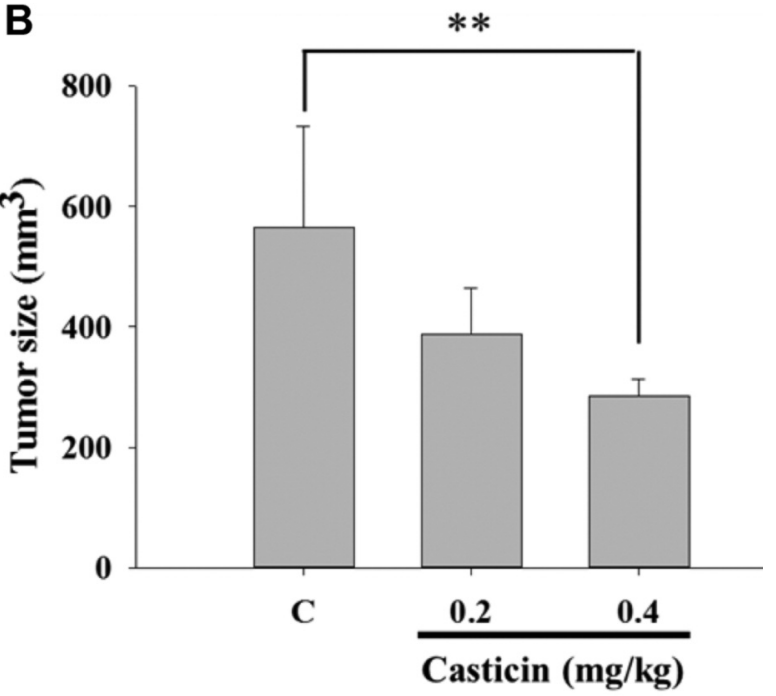

Figure 3. The effects of casticin on tumor size (volume) in SCC-4 cell xenograft mice. The tumor volume was measured every two days for 18 days. The differences between control and $0.2 \mathrm{mg} / \mathrm{kg}$ treatment, or control and $0.4 \mathrm{mg} / \mathrm{kg}$ treatment were statistically significant (p<0.05).

inhibited cell proliferation in leukemia cells (21) in vitro. Casticin suppressed esophageal cancer cell proliferation and induced apoptosis in vitro, and its in vivo anti-tumor action was shown to be partly mediated via mitochondrial-dependent apoptosis and activation of JNK signaling pathway (22). Furthermore, it has been reported that casticin induced DNA damage and suppressed DNA repair associated proteins in mouse melanoma B16F10 cells (23).

Besides, casticin suppressed EMT in hepatocellular carcinoma and inhibited lung cancer cell migration and invasion in vitro (24) and it also suppressed migration of mouse melanoma cells $(25,26)$. Moreover, casticin has been shown to present anti-inflammatory effects in preclinical models $(13,27)$. It has also been shown to inhibit lipopolysaccharide (LPS)-induced lung injury through affecting inflammatory cytokines (TNF- $\alpha$, IL-6, and IL-1 $\beta$ ) (28), and to attenuate liver fibrosis and hepatic stellate cell activation via the inhibition of the TGF- $\beta /$ Smad signaling pathway (29). Thus, it may have therapeutic potential for inflammatory lung diseases (27).

Recently, we found that casticin promotes immune responses, enhances phagocytosis of macrophages and NK cell activities in animal models in vivo (30). However, the anti-tumor activity of casticin in animal models of human oral cancer cell xenografts is still unclear. Thus, in the present study, the antitumor activity of casticin in xenografted mouse models of SCC-4 human oral cancer cells were investigated. We found that casticin significantly reduced tumor volume in SCC-4 cell xenograft mouse in vivo.

\section{Materials and Methods}

Chemicals and Reagents. Casticin with a purity of $99 \%$, cell culture grade dimethyl sulfoxide (DMSO), Tris- $\mathrm{HCl}$, and trypan blue were obtained from Sigma Chemical Co. (St. Louis, MO, USA). DMEM:F12 medium, fetal bovine serum (FBS), L-glutamine, and antibiotics (penicillin-streptomycin) were purchased from GIBCO ${ }^{\circledR} /$ Invitrogen Life Technologies (Grand Island, NY, USA). The stock solution of casticin $(100 \mathrm{mg} / \mathrm{ml})$ was dissolved in DMSO and diluted in cell culture medium before use. DMSO as used as the vehicle at $0.1 \%$.

Cell line and culture. Human oral cancer SCC-4 cell line was obtained from the Food Industry Research and Development Institute (Hsinchu, Taiwan, R.O.C.) and cultured based on the supplier's instructions. Cells were cultured in DMEM:F12 medium containing 10\% FBS, 2 mM L-glutamine, and 1\% antibiotics (100 Units $/ \mathrm{ml}$ of penicillin and $100 \mu \mathrm{g} / \mathrm{ml}$ of streptomycin). SCC-4 cells were maintained at $37^{\circ} \mathrm{C}$ in a humidified atmosphere $5 \% \mathrm{CO}_{2}$ and $95 \%$ air in a $75 \mathrm{~cm}^{2}$ tissue culture flasks as described previously (31).

Animals and treatments. Twenty-four athymic male mice (CAnN.Cg-Foxn1 ${ }^{n u / C r l N a r l ~ n u d e ~ m i c e) ~ a g e d ~ s i x ~ w e e k s, ~ w i t h ~ 20-25 ~}$ g body weight, were purchased from the National Laboratory Animal Center, Taipei, Taiwan, and followed the National Institutes of Health Guidelines for Animal Research. All mice were housed in the Animal Center of China Medical University (Taichung, Taiwan, R.O.C.) and were adapted to the environment one week before the experiment. The animal study was approved and issued by the Institutional Animal Care and Use Committee of China Medical University (number: 105-17).

The experimental design is shown in Figure 1. Human oral cancer SCC-4 cells $\left(1 \times 10^{7}\right)$ in $100 \mu \mathrm{l}$ mixture containing serum-free DMEM:F12 medium and Matrigel (1:1) were subcutaneously 


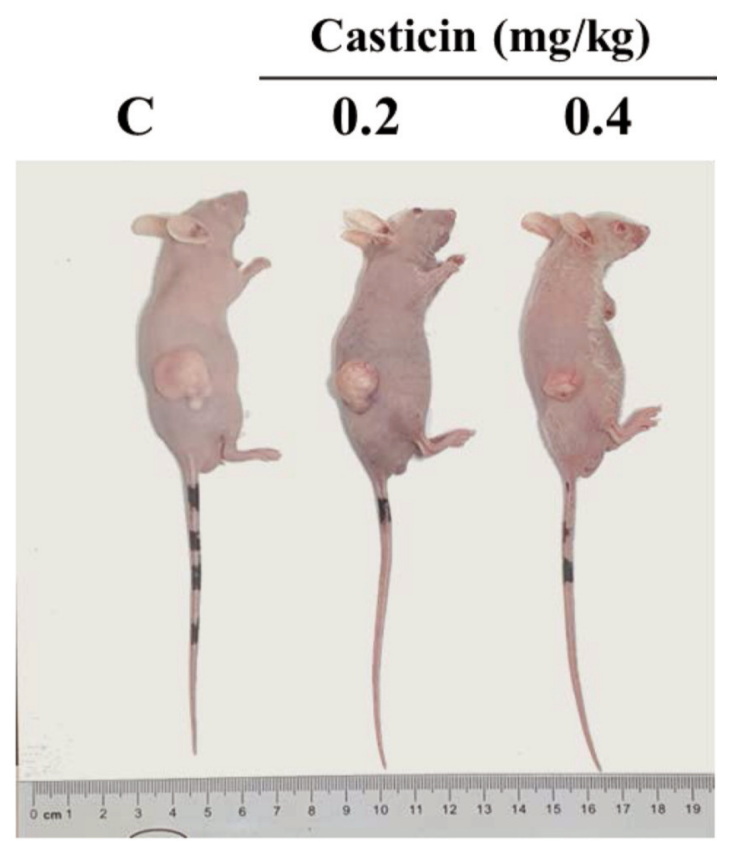

Figure 4. The anti-tumor effect of casticin in SCC-4 cell xenograft mice. The tumor growth in each mouse was monitored and the representative tumors from three mouse groups are presented after 18 days of treatment.

inoculated into the right hind legs of the 24 mice (32). All mice were randomized into three different treatment groups [control, $0.2 \mathrm{mg} / \mathrm{kg}$ (I), and $0.4 \mathrm{mg} / \mathrm{kg}$ (II) casticin groups] ( $\mathrm{n}=8$ for each group) when the tumor volume reached $100-120 \mathrm{~mm}^{3}$ in each mouse. The tumor volume of the individual mouse was measured with a digital caliper and calculated with the equation: tumor volume $=0.523 \times$ length $\times$ width $^{2}$ (32). The control animal group ( $\mathrm{n}=8)$ was intraperitoneally injected every two days for 18 days with $90 \mu$ phosphate-buffered solution (PBS) plus $10 \mu \mathrm{l}$ DMSO. Experimental groups I and II were intraperitoneally injected every two days for 18 days with $0.2 \mathrm{mg} / \mathrm{kg}$ and $0.4 \mathrm{mg} / \mathrm{kg}$ casticin, respectively. Tumor growth, tumor volume, and body weight were monitored. After the final drug administration, all mice were sacrificed immediately and dissected for isolating tumor and weight tumor individually, as described previously (32).

Statistical analysis. The data are presented as the means \pm standard deviation (Mean \pm S.D.). The comparison between casticin-treated and control groups was examined by using one-way ANOVA with Newman-Keuls multi-comparison test. $p<0.05$ was considered to indicate a statistically significant difference between control and experimental groups.

\section{Results}

Casticin affected the body weights in xenograft SCC-4 cellbearing mice. To determine the antitumor effects of casticin in vivo, SCC-4 cells were subcutaneously injected into the right hind legs of nude mice to establish an SCC-4 cell xenograft tumor model. During treatment with casticin, the
A Casticin (mg/kg)
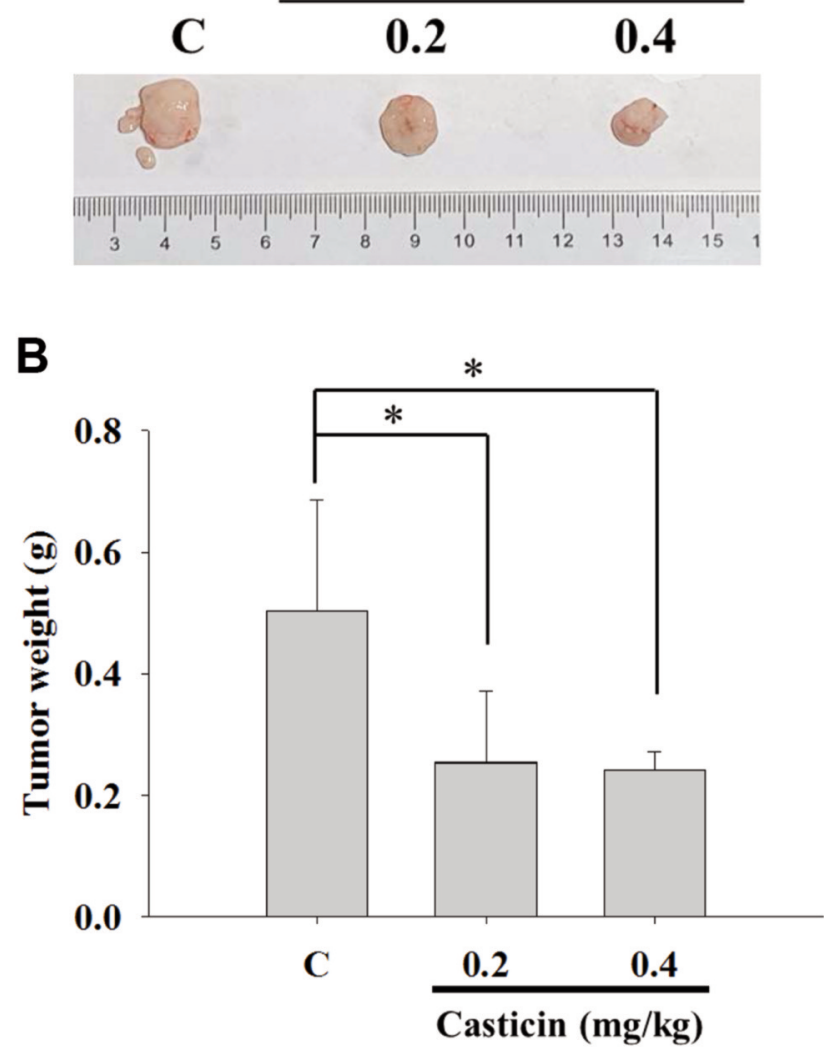

Figure 5. The anti-tumor effect of casticin in SCC-4 cell xenograft mice. (A) Representative tumors from the 3 mouse groups are presented. (B) Casticin at both doses (0.2 and $0.4 \mathrm{mg} / \mathrm{kg})$ significantly suppressed tumor size compared to the control group $(* p<0.05$ and $* * * p<0.001)$.

body weight of each individual mouse of each group was measured and recorded every two days for a total of 18 days and the results are presented in Figure 2. Figure 2 indicates that the total body weight of each group was not altered following treatment without (control) or with casticin $(0.2$ $\mathrm{mg} / \mathrm{kg}$ and $0.4 \mathrm{mg} / \mathrm{kg}$ of casticin). Furthermore, each mouse displayed normal behavior, indicative of good tolerability of casticin and no signs of acute or delayed toxicity of casticin in SCC-4 cell xenograft mice.

Casticin inhibited SCC-4 cell xenograft tumor growth. When the tumor size reached an approximate volume of 100-120 $\mathrm{mm}^{3}$, the mice were treated with $0.1 \%$ DMSO/PBS or casticin $(0.2$ and $0.4 \mathrm{mg} / \mathrm{kg})$ every two days for 18 days. The tumor size (volume) in each mouse of each group was measured every two days and the results are presented in Figure 3. After 16-days of treatment, casticin at $0.4 \mathrm{mg} / \mathrm{kg}$ slightly decreased the rate of increase of tumor volume (Figure 3A) and at the end of treatment, it significantly decreased tumor size (Figure 3B) compared to the control 
group. These results indicated that both doses of casticin inhibited tumor volume by $25 \%$ and $40 \%$ compared with the control (Figure 3B), and the higher dose $(0.4 \mathrm{mg} / \mathrm{kg})$ of casticin significantly reduced the tumor volume (Figure $3 \mathrm{~B}$ ).

After 18-days of treatment, all mice were anesthetized with isoflurane. Representative animals with tumors are shown in Figure 4. Subsequently, tumors were collected and a representative from each group is presented in Figure 5A. The tumor weights were measured and the average tumor weight \pm S.D. for each group is presented in Figure $5 B$. Both doses of casticin $(0.2$ and $0.4 \mathrm{mg} / \mathrm{kg})$ considerably reduced tumor weight by $50 \%$ and $52 \%$, respectively, in comparison with the control group (Figure 5B).

\section{Discussion}

The current study was based on our previous studies indicating that casticin was cytotoxic (reduced the total number of viable cells) through $\mathrm{G}_{2} / \mathrm{M}$ phase arrest and induction of apoptosis by caspase- and mitochondria-dependent pathways in SCC-4 cells in vitro (33). However, there was no information regarding the effects of casticin on SCC-4 cells in vivo; thus, we investigated the in vivo antitumor activity of casticin by using a mouse xenograft model. SCC-4 cells were injected into mice and tumor growth was monitored and recorded. The results indicated that after 18-day treatment, casticin suppressed tumor growth based on the reduction of tumor volume by $25 \%$ and $40 \%$ (Figure 3B) and tumor weight by $50 \%$ and $52 \%$ (Figure $5 B$ ), following treatment with 0.2 and $0.4 \mathrm{mg} / \mathrm{kg} / \mathrm{day}$ of casticin, respectively. Furthermore, casticin had no significant effect on mouse body weight in subcutaneous xenograft tumors of human oral cancer SCC-4 cells-bearing mice in vivo. Therefore, in the future, we will examine the cytotoxic effects of casticin in vivo in normal mice.

Currently, the preventive and therapeutic protocols for patients with oral cancer depend upon the stage of cancer and the typical clinical treatments of oral cancer include surgery, radiation, and chemotherapy; however, drug resistance and side-effects (toxicity in normal cells) accompany treatment. Therefore, many studies have focused on new approaches or compounds from natural products to overcome the side effects of current chemotherapy drugs including cytotoxicity and drug resistance. Furthermore, we have reported that casticin was cytotoxic for cancer cells; decreased the total number of viable cells, induced cell cycle arrest, and apoptosis of SCC-4 cells in vitro. These findings are in agreement with other reports indicating that casticin suppresses the proliferation of different tumor cells $(11,22,35,36)$. Importantly, casticin had no effects on cell proliferation and prolactin release in nonstimulated primary pituitary cells in vitro (17).

Our results indicated that casticin significantly suppressed the tumor volume (Figure 3) and weight (Figure 5B) in SCC4 cell xenograft nude mice in vivo and these findings are in agreement with our earlier reports in a human melanoma A375.S2 cell xenografted model in vivo (25).

It is well known that putative drugs should be investigated in cancer cells and then cancer cell xenograft animal models in vivo before used in clinical trials $(34,37-40)$. Herein, we demonstrate for the first time that casticin has anti-oral tumor potential in an animal model. Further investigations regarding the molecular mechanism of the inhibitory effects of casticin on tumor volume, size, and weight in SCC-4 cell xenograft nude mice in vivo are warranted.

In conclusion, casticin inhibited the growth of ectopic xenograft tumors of SCC-4 cells in vivo.

\section{Conflicts of Interest}

The Authors confirm that there are no conflicts of interest regarding this study.

\section{Authors' Contributions}

Data curation: Hung-Sheng Shang, Kuo-Wei Chen, Jiann-Shang Chou, Shu-Fen Peng and Yung-Liang Chen,; Funding acquisition: Hung-Sheng Shang and Yung-Luen Shih; Methodology: HungSheng Shang, Po-Yuan Chen and Hsieh-Chou Huang; Validation: Hung-Sheng Shang, Kuo-Wei Chen, Hsu-Feng Lu and Hsin-Yu Chang; Writing - original draft: Hung-Sheng Shang, Shu-Fen Peng, Yung-Luen Shih and Wen-Wen Huang; Writing - review and editing: Hung-Sheng Shang, Yung-Luen Shih and Wen-Wen Huang.

\section{Acknowledgements}

This study was supported by the grant 108-09 from Cheng Hsin General Hospital and 2019SKHAND007 from Shin Kong Wu HoSu Memorial Hospital, Taipei, Taiwan.

\section{References}

1 Feller L and Lemmer J: Oral squamous cell carcinoma: Epidemiology, clinical presentation and treatment. J Cancer Ther 3: 6, 2012. DOI: $10.4236 /$ jct.2012.34037

2 Parkin DM, Bray F, Ferlay J and Pisani P: Global cancer statistics, 2002. CA Cancer J Clin 55: 74-108, 2005. PMID: 15761078. DOI: $10.3322 /$ canjclin.55.2.74

3 Silverman S, Jr. and Gorsky M: Epidemiologic and demographic update in oral cancer: California and national data-1973 to 1985. J Am Dent Assoc 120: 495-499, 1990. PMID: 2335670. DOI: 10.14219/jada.archive. 1990.0082

4 Bagan J, Sarrion G and Jimenez Y: Oral cancer: clinical features. Oral Oncol 46: 414-417, 2010. PMID: 20400366. DOI: 10.1016/ j.oraloncology.2010.03.009

5 Whitmore SE and Lamont RJ: Oral bacteria and cancer. PLoS Pathog 10: e1003933, 2014. PMID: 24676390. DOI: 10.1371/ journal.ppat.1003933

6 National Cancer Institute: Surveillance, Epidemiology, and end results program, Cancer Stat Facts, oral cavity and pharynx cancer. 2016. Available at: https://seer.cancer.gov/statfacts/html/ oralcav.html [Last accessed June 24, 2020] 
7 Canadian Cancer Society's Advisory Committee on Cancer Statistics. Canadian Cancer Statistics. Toronto, ON: Canadian Cancer Society.

8 Welfare TMoHa: 2018 Taiwan Health and Welfare Report, 2019. Available at: https://www.mohw.gov.tw/cp-137-47558-2.html

9 Lin YS, Jen YM, Wang BB, Lee JC and Kang BH: Epidemiology of oral cavity cancer in taiwan with emphasis on the role of betel nut chewing. ORL J Otorhinolaryngol Relat Spec 67: 230-236, 2005. PMID: 16254455. DOI: 10.1159/000089214

10 Rasul A, Zhao BJ, Liu J, Liu B, Sun JX, Li J and Li XM: Molecular mechanisms of casticin action: an update on its antitumor functions. Asian Pac J Cancer Prev 15: 9049-9058, 2014. PMID: 25422178. DOI: 10.7314/apjcp.2014.15.21.9049

11 Lee JH, Kim C, Ko JH, Jung YY, Jung SH, Kim E, Kong M, Chinnathambi A, Alahmadi TA, Alharbi SA, Sethi G and Ahn KS: Casticin inhibits growth and enhances ionizing radiationinduced apoptosis through the suppression of STAT3 signaling cascade. J Cell Biochem 120: 9787-9798, 2019. PMID: 30520154. DOI: $10.1002 /$ jcb.28259

12 You KM, Son KH, Chang HW, Kang SS and Kim HP: Vitexicarpin, a flavonoid from the fruits of Vitex rotundifolia, inhibits mouse lymphocyte proliferation and growth of cell lines in vitro. Planta Med 64: 546-550, 1998. PMID: 9741302. DOI: $10.1055 / \mathrm{s}-2006-957511$

13 Lin S, Zhang H, Han T, Wu JZ, Rahman K and Qin LP: In vivo effect of casticin on acute inflammation. Zhong Xi Yi Jie He Xue Bao 5: 573-576, 2007. PMID: 17854563. DOI: 10.3736/ jcim20070520

14 Lee SM, Lee YJ, Kim YC, Kim JS, Kang DG and Lee HS: Vascular protective role of vitexicarpin isolated from Vitex rotundifolia in human umbilical vein endothelial cells. Inflammation 35: 584-593, 2012. PMID: 21614554. DOI: 10.1007/s10753-011-9349-x

15 Shiue YW, Lu CC, Hsiao YP, Liao CL, Lin JP, Lai KC, Yu CC, Huang YP, Ho HC and Chung JG: Casticin induced apoptosis in A375.S2 human melanoma cells through the inhibition of NFkappaB and mitochondria-dependent pathways in vitro and inhibited human melanoma xenografts in a mouse model in vivo. Am J Chin Med 44: 637-661, 2016. PMID: 27109154. DOI: $10.1142 / \mathrm{s} 0192415 \times 1650035 \mathrm{x}$

16 Li YJ, Guo Y, Yang Q, Weng XG, Yang L, Wang YJ, Chen Y, Zhang D, Li Q, Liu XC, Kan XX, Chen X, Zhu XX, Kmoniekova $\mathrm{E}$ and Zidek $\mathrm{Z}$ : Flavonoids casticin and chrysosplenol D from Artemisia аппиа L. inhibit inflammation in vitro and in vivo. Toxicol Appl Pharmacol 286: 151-158, 2015. PMID: 25891417. DOI: 10.1016/j.taap.2015.04.005

17 Ye Q, Zhang QY, Zheng CJ, Wang Y and Qin LP: Casticin, a flavonoid isolated from Vitex rotundifolia, inhibits prolactin release in vivo and in vitro. Acta Pharmacol Sin 31: 1564-1568, 2010. PMID: 21042288. DOI: 10.1038/aps.2010.178

18 Song XL, Zhang YJ, Wang XF, Zhang WJ, Wang Z, Zhang F, Zhang YJ, Lu JH, Mei JW, Hu YP, Chen L, Li HF, Ye YY, Liu YB and $\mathrm{Gu} J$ : Casticin induces apoptosis and $\mathrm{G}_{0} / \mathrm{G}_{1}$ cell cycle arrest in gallbladder cancer cells. Cancer Cell Int 17: 9, 2017. PMID: 28070171. DOI: 10.1186/s12935-016-0377-3

19 Zeng F, Tian L, Liu F, Cao J, Quan M and Sheng X: Induction of apoptosis by casticin in cervical cancer cells: reactive oxygen species-dependent sustained activation of Jun N-terminal kinase. Acta Biochim Biophys Sin (Shanghai) 44: 442-449, 2012. PMID: 22427461. DOI: 10.1093/abbs/gms013
20 Jiang L, Cao XC, Cao JG, Liu F, Quan MF, Sheng XF and Ren $\mathrm{KQ}$ : Casticin induces ovarian cancer cell apoptosis by repressing FoxM1 through the activation of FOXO3a. Oncol Lett 5: 16051610, 2013. PMID: 23761826. DOI: 10.3892/ol.2013.1258

21 Kikuchi H, Yuan B, Nishimura Y, Imai M, Furutani R, Kamoi S, Seno M, Fukushima S, Hazama S, Hirobe C, Ohyama K, Hu XM, Takagi N, Hirano T and Toyoda H: Cytotoxicity of Vitex agnus-castus fruit extract and its major component, casticin, correlates with differentiation status in leukemia cell lines. Int $\mathbf{J}$ Oncol 43: 1976-1984, 2013. PMID: 24126491. DOI: 10.3892/ ijo.2013.2133

22 Qiao Z, Cheng Y, Liu S, Ma Z, Li S and Zhang W: Casticin inhibits esophageal cancer cell proliferation and promotes apoptosis by regulating mitochondrial apoptotic and JNK signaling pathways. Naunyn Schmiedebergs Arch Pharmacol 392: 177-187, 2019. PMID: 30448926. DOI: 10.1007/s00210018-1574-5

23 Shih YL, Chou J, Yeh MY, Chou HM, Chou HC, Lu HF, Shang HS, Chueh FS, Chu YL, Hsueh SC and Chung JG: Casticin induces DNA damage and inhibits DNA repair-associated protein expression in $\mathrm{B} 16 \mathrm{~F} 10$ mouse melanoma cancer cells. Oncol Rep 36: 2094-2100, 2016. PMID: 27572101. DOI: 10.3892/or.2016.5027

$24 \mathrm{He}$ M, Cao XC, He GC, Sheng XF, Ai XH and Wu YH: Casticin inhibits epithelial-mesenchymal transition of liver cancer stem cells of the SMMC-7721 cell line through downregulating Twist. Oncol Lett 7: 1625-1631, 2014. PMID: 24765190. DOI: 10.3892/ol.2014.1899

25 Shiue YW, Lu CC, Hsiao YP, Liao CL, Lin JP, Lai KC, Yu CC, Huang YP, Ho HC and Chung JG: Casticin induced apoptosis in A375.S2 Human melanoma cells through the inhibition of NF$\mathrm{kB}$ and mitochondria-dependent pathways in vitro and inhibited human melanoma xenografts in a mouse model in vivo. Am J Chin Med 44: 637-661, 2016. PMID: 27109154. DOI: 10.1142/ s0192415x1650035x

26 Shih YL, Chou HM, Chou HC, Lu HF, Chu YL, Shang HS and Chung JG: Casticin impairs cell migration and invasion of mouse melanoma B16F10 cells via PI3K/AKT and NF-kappaB signaling pathways. Environ Toxicol 32: 2097-2112, 2017. PMID: 28444820. DOI: 10.1002/tox.22417

27 Lee H, Jung KH, Lee H, Park S, Choi W and Bae H: Casticin, an active compound isolated from Vitex Fructus, ameliorates the cigarette smoke-induced acute lung inflammatory response in a murine model. Int Immunopharmacol 28: 1097-1101, 2015. PMID: 26321116. DOI: 10.1016/j.intimp.2015.07.041

28 Wang C, Zeng L, Zhang T, Liu J and Wang W: Casticin inhibits lipopolysaccharide-induced acute lung injury in mice. Eur J Pharmacol 789: 172-178, 2016. PMID: 27450485. DOI: 10.1016/j.ejphar.2016.07.035

29 Zhou L, Dong X, Wang L, Shan L, Li T, Xu W, Ding Y, Lai M, Lin X, Dai M, Bai X, Jia C and Zheng H: Casticin attenuates liver fibrosis and hepatic stellate cell activation by blocking TGF-beta/Smad signaling pathway. Oncotarget 8: 56267-56280, 2017. PMID: 28915589. DOI: 10.18632/oncotarget.17453

30 Lai KC, Lu HF, Chen KB, Hsueh SC, Chung JG, Huang WW, Chen CC and Shang HS: Casticin promotes immune responses, enhances macrophage and NK cell activities, and increases survival rates of leukemia BALB/c mice. Am J Chin Med 47: 223-236, 2019. PMID: 30630343. DOI: 10.1142 s0192415x19500113 
31 Yu FS, Huang AC, Yang JS, Yu CS, Lu CC, Chiang JH, Chiu CF and Chung JG: Safrole induces cell death in human tongue squamous cancer SCC-4 cells through mitochondria-dependent caspase activation cascade apoptotic signaling pathways. Environ Toxicol 27: 433-444, 2012. PMID: 21591240. DOI: 10.1002/tox.20658

32 Li CC, Yu FS, Fan MJ, Chen YY, Lien JC, Chou YC, Lu HF, Tang NY, Peng SF, Huang WW and Chung JG: Anticancer effects of cantharidin in A431 human skin cancer (Epidermoid carcinoma) cells in vitro and in vivo. Environ Toxicol 32: 723738, 2017. PMID: 27113412. DOI: 10.1002/tox.22273

33 Chou GL, Peng SF, Liao CL, Ho HC, Lu KW, Lien JC, Fan MJ, La KC and Chung JG: Casticin impairs cell growth and induces cell apoptosis via cell cycle arrest in human oral cancer SCC-4 cells. Environ Toxicol 33: 127-141, 2018. PMID: 29098808. DOI: $10.1002 /$ tox.22497

34 Ni WY, Lu HF, Hsu SC, Hsiao YP, Liu KC, Liu JY, Ji BC, Hsueh SC, Hung FM, Shang HS and Chung JG: Phenethyl isothiocyanate inhibits in vivo growth of subcutaneous xenograft tumors of human malignant melanoma A375.S2 cells. In Vivo 28: 891-894, 2014. PMID: 25189905.

35 Lee JH, Kim C, Um JY, Sethi G and Ahn KS: Casticin-induced inhibition of cell growth and survival are mediated through the dual modulation of Akt/mTOR signaling cascade. Cancers (Basel) 11, 2019. PMID: 30813295. DOI: 10.3390/cancers 11020254

36 Yang F, He K, Huang L, Zhang L, Liu A and Zhang J: Casticin inhibits the activity of transcription factor $\mathrm{Sp} 1$ and the methylation of RECK in MGC803 gastric cancer cells. Exp Ther Med 13: 745-750, 2017. PMID: 28352361. DOI: 10.3892/etm. 2016.4003
37 Pitts TM, Tan AC, Kulikowski GN, Tentler JJ, Brown AM, Flanigan SA, Leong S, Coldren CD, Hirsch FR, Varella-Garcia M, Korch C and Eckhardt SG: Development of an integrated genomic classifier for a novel agent in colorectal cancer: approach to individualized therapy in early development. Clin Cancer Res 16: 3193-3204, 2010. PMID: 20530704. DOI: 10.1158/1078-0432.ccr-09-3191

38 Tentler JJ, Tan AC, Weekes CD, Jimeno A, Leong S, Pitts TM, Arcaroli JJ, Messersmith WA and Eckhardt SG: Patient-derived tumour xenografts as models for oncology drug development. Nat Rev Clin Oncol 9: 338-350, 2012. PMID: 22508028. DOI: 10.1038/nrclinonc.2012.61

39 Fiebig HH, Maier A and Burger AM: Clonogenic assay with established human tumour xenografts: correlation of in vitro to in vivo activity as a basis for anticancer drug discovery. Eur $\mathrm{J}$ Cancer 40: 802-820, 2004. PMID: 15120036. DOI: 10.1016/ j.ejca.2004.01.009

40 Hidalgo M, Bruckheimer E, Rajeshkumar NV, Garrido-Laguna I, De Oliveira E, Rubio-Viqueira B, Strawn S, Wick MJ, Martell J and Sidransky D: A pilot clinical study of treatment guided by personalized tumorgrafts in patients with advanced cancer. Mol Cancer Ther 10: 1311-1316, 2011. PMID: 21673092. DOI: 10.1158/1535-7163.mct-11-0233

Received March 16, 2020

Revised June 22, 2020

Accepted June 24, 2020 